\title{
The Responses of Rat Intestinal Mucosa, Epithelial Cell Renewal and Plasma Lipoprotein to Intravenous Feeding
}

\author{
Mieko KAWAMURA and Shuichi KIMURA ${ }^{1}$ \\ Laboratory of Nutrition, Faculty of Agriculture, \\ Tohoku University, Sendai, Miyagi 980, Japan
}

(Received January 20, 1981)

\begin{abstract}
Summary Healthy young rats were fed on fat-free diets, $85 \%$ of the energy of which derived from glucose and $15 \%$ from amino acids. The composition of the intravenous infusates was adequate to maintain body weight during a 6-day experimental period. Mucosal wet and dry weight, and mucosal protein content were highest when the diet was given orally, intermediate when given intravenously, and lowest when fasting. The DNA content of mucosa was significantly lower following intravenous feeding or fasting than after oral feeding, and there was no significant difference between intravenous feeding and fasting. The composition of mucosal protein following intravenous feeding differed from that following oral feeding or fasting. The migration of jejunum epithelial cells was prolonged following intravenous feeding compared with that after oral feeding. The values of plasma albumin and glucose concentration showed no differences between the intravenous and oral feeding groups. In contrast, intravenous feeding greatly lowered the total plasma cholesterol, HDL-cholesterol and HDL-cholesterol/LDL-cholestrol ratio. LDLcholesterol levels were not changed.
\end{abstract}

Key Words intravenous feeding, fasting, cell migration, rat small intestine, plasma lipoprotein

Little is known about how the presence of food in the intestinal tract influences the structural and functional integrity of the small intestine. Although the morphologic or functional events of changes in the intestinal tract have been well defined in the absence of food, it has been impossible to separate the effects of the absence of food from the effects of starvation, and less is known concerning the mechanism by which the effect of oral intake behavior is mediated.

As reported previously, intravenous alimentation maintains the intestinal function during a 6-day experimental period, whereas it was apparent that the shape of jejunum villi observed differed from that of rats fed orally or fasted (1). This

1 川村美笑子，木村修一 
paper reports the responses to intravenous feeding of the intestinal mucosa, epithelial cell renewal and plasma lipoprotein in rat in comparison with those with oral feeding or fasting.

\section{MATERIALS AND METHODS}

Animals and diets. Twenty-five male Sprague-Dawley rats, 6 weeks old weighing 178 to $185 \mathrm{~g}$, were divided into three groups. One group received nutrients intravenously, consuming 35 to $50 \mathrm{ml} /$ day, with a constant infusion pump (Gilson Peristaltic Pump: Minipulus HP4). This solution contained no fat, but provided $1.0 \mathrm{kcal} / \mathrm{ml}$. Amino acid and glucose contributed $15 \%$ and $85 \%$ of the total energy, respectively. Electrolytes and vitamins were added as required (2). In the second group, an equal volume of nutrient solution was given orally. In the third group, the animals were given water without diet. Intravenous alimentation was carried out according to the method of Steiger and coworkers (3). In the brief, under sodium pentobarbital anesthesia, a catheter was inserted into the right jugular vein through a supraclavicular incision and advanced to the right atrium. Each animal was prepared for continuous infusion by connecting it to a freely rotating swivel (manufactured by Laboratory of Nutrition, Tohoku University, Japan). After 6 days of intravenous, oral or fasted alimentation, the animals were killed.

Autoradiographic procedure. Microautography of the small intestinal epithelium was undertaken according to the method of Matsuzawa (4). The animals received intraperitoneal injection of (methyl-3H)thymidine, $0.5 \mu \mathrm{C}$ per $\mathrm{g}$ of body weight (specific activity $25 \mu \mathrm{C}$ per mmol, Radiochemical Center, Amersham, England). Each animal was killed an appropriate time after isotope injection and body weight was measured. The wet weight of a $50 \mathrm{~cm}$-long segment of the proximal jejunum lacking any contents was also measured. Mucosa was then separated by scraping with the edge of a microscope slide and dried in a vacuum desiccator for $48 \mathrm{hr}$ at room temperature to obtain mucosal dry weight.

At each time interval a one-cm long segment from the proximal two-fifths of the small intestine and the middle jejunum were removed from animals which had undergone intravenous or oral feeding, or fasting. These samples were immediately fixed in a solution of $10 \%$ neutral formalin and paraffin sections $(5 \mu)$ were processed for dipping autoradiography using SAKURA-M2 emulsion. The slides were stored in black boxes and maintained in a dark room at $4^{\circ} \mathrm{C}$. After 3 weeks of exposure, the slides were developed in Konidol $\mathrm{X}$ for $5 \mathrm{~min}$ at $20^{\circ} \mathrm{C}$. The sections were then stained with hematoxylin eosin and the villus cell number covered by radioactive grains visualized over nuclei was determined. Only villi demonstrating a vertical line from the base of the crypt to the tip of the villus were measured.

Gel filtration. One $\mathrm{ml}$ of $105,000 \times g$ supernatant from mucosal homogenates was placed on a Sephadex G-200 column $(1.3 \times 90 \mathrm{~cm})$. The protein was eluted with

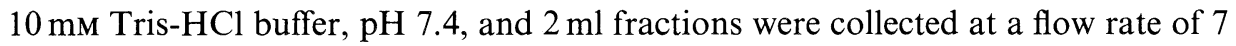


$\mathrm{ml} / \mathrm{hr}$.

Collection of rat blood and separation of plasma. Blood was obtained from the abdominal aorta of rats anesthetized with ether. The blood was drawn into heparinized syringes and centrifuged immediately. Plasma was prepared by the routine method.

Chemical analysis. Mucosal protein and DNA analyses have been described in a previous report(1). The concentrations of plasma glucose and albumin were determined by Glucose-Test (Wako Pure Chemical Industries, Ltd.) and the method of Martinek (5), respectively.

Plasma cholesterol was determined by the cholesterol B-Test (Wako Pure Chemical Industries, Ltd.).

Isolation of lipoprotein fractions. One hundred and seventy-five microliters of plasma were centrifuged (Beckman Airfuge) for $2.5 \mathrm{hr}$ at $100,000 \mathrm{rpm}$. Plasma lipoproteins were quantified by cholesterol content. Cholesterol was measured in plasma and bottom fractions of each tube centrifuged, at the density of plasma and at a density of 1.06 respectively, by addition of dry sodium bromide. Top and bottom fractions were separated by air aspiration (Beckman Airfuge Tube Fractionator): the value for LDL-cholesterol was obtained by subtracting that for HDL-cholesterol (bottom fraction of each tube centrifuged at a density of 1.06) from that for $\mathrm{LDL}+\mathrm{HDL}$ cholesterol (bottom fraction of each tube centrifuged at plasma density).

Statistical analysis. Data were treated statistically using student's $t$-test. All data were expressed as the mean \pm standard error.

\section{RESULTS}

\section{Body weight and small intestinal measurement}

Body weight gain and small intestinal measurement are shown in Table 1. Average body weight of the three groups of rats ranged from 178 to $185 \mathrm{~g}$ at the beginning of experiment. Weight gain was noted both in rats fed intravenously and orally, whereas a significant weight loss occurred in fasted rats. At the end of the experiment, the average of wet weight per unit length $(\mathrm{mg} / \mathrm{cm})$ of jejunum was greatest in the rats fed orally and intermediate in the rats fed intravenously. Mucosal wet weight paralleled total small-intestinal wet weight. Similar to the wet weight findings, mucosal dry weight was greatest in the rats fed orally, intermediate in the rats fed intravenously, and lowest in the fasted rats. Mucosal protein content paralleled mucosal wet or dry weight: orally greatest, intravenously intermediate, and fasted lowest. In the intravenously fed rats and fasted rats, total DNA content of the jejunum mucosa was significantly lower than that of the rats fed orally. There was no significant difference between the intravenously fed and fasted rats, but when expressed in terms of protein a difference was detectable. 
Table 1. Rat body weight and small intestinal measurement in the three different groups of nutrition.

\begin{tabular}{|c|c|c|c|c|}
\hline & $\begin{array}{l}\text { Intravenously } \\
\text { fed }\end{array}$ & $\begin{array}{l}\text { Orally } \\
\text { fed }\end{array}$ & Fasted & $\begin{array}{c}\text { Statistical } \\
\text { comparison* }\end{array}$ \\
\hline Number of rats & 8 & 9 & 8 & \\
\hline \multicolumn{5}{|l|}{ Body weight (g) } \\
\hline Initial & $178 \pm 6.0$ & $185 \pm 4.0$ & $180 \pm 5.0$ & N.S. \\
\hline Final & $185 \pm 7.0$ & $200 \pm 6.0$ & $135 \pm 6.0$ & I.V. $>\mathrm{F} ; \mathrm{O}>\mathrm{F}$ \\
\hline \multicolumn{5}{|l|}{ Small intestinal measurements } \\
\hline Wet weight $(\mathrm{mg} / \mathrm{cm})$ & $34 \pm 2.0$ & $42 \pm 1.0$ & $30 \pm 2.0$ & $\mathrm{O}>\mathrm{I} . \mathrm{V} . ; \mathrm{O}>\mathrm{F}$ \\
\hline Mucosal wet weight $(\mathrm{mg} / \mathrm{cm})$ & $8.0 \pm 0.6$ & $14.0 \pm 0.8$ & $6.9 \pm 0.3$ & $\mathrm{O}>\mathrm{I} . \mathrm{V} . ; \mathrm{O}>\mathrm{F}$ \\
\hline Mucosal dry weight $(\mathrm{mg} / \mathrm{cm})$ & $1.6 \pm 0.3$ & $2.8 \pm 0.5$ & $0.8 \pm 0.2$ & $\begin{array}{l}\mathrm{O}>\mathrm{I} . \mathrm{V} . \\
\text { I.V. }>\mathrm{F}\end{array}$ \\
\hline Mucosal protein $(\mathrm{mg} / \mathrm{cm})$ & $0.7 \pm 0.09$ & $1.1 \pm 0.08$ & $0.3 \pm 0.05$ & $\begin{array}{l}\mathrm{O}>\mathrm{I} . \mathrm{V} . \\
\text { I.V. }>\text { F }\end{array}$ \\
\hline Mucosal DNA (mg/cm) & $0.05 \pm 0.004$ & $0.08 \pm 0.005$ & $0.05 \pm 0.006$ & $\mathrm{O}>$ I.V.; $\mathrm{O}>\mathrm{F}$ \\
\hline
\end{tabular}

* Indicates statistically significant difference among the 3 groups, $p<0.05$. N.S.: no significant difference between data sets, $p<0.05$. I.V., O, and F: mean intravenously, orally, and fasted, respectively.

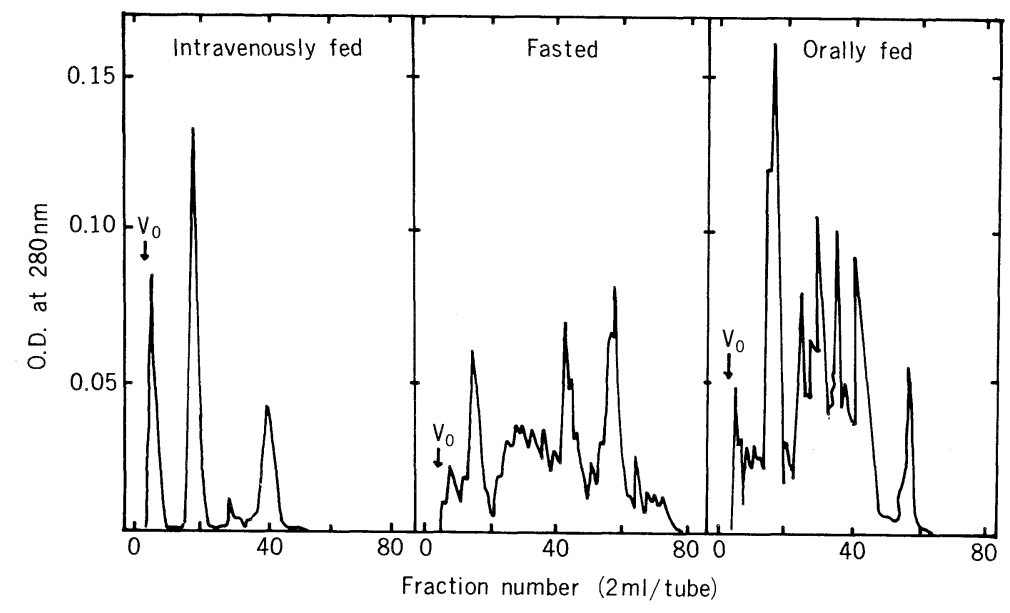

Fig. 1. Elution patterns of mucosal protein on Sephadex G-200.

\section{Gel filtration}

The $105,000 \times g$ supernatant fraction obtained from the jejunum mucosal homogenates of rats fed intravenously, orally or fasted was fractionated in order to separate the different molecular sizes. Figure 1 shows typical elution patterns obtained from each group of animals. In elution patterns of rats fed orally, high molecular weight protein emerged as a major peak near the void volume, and this 


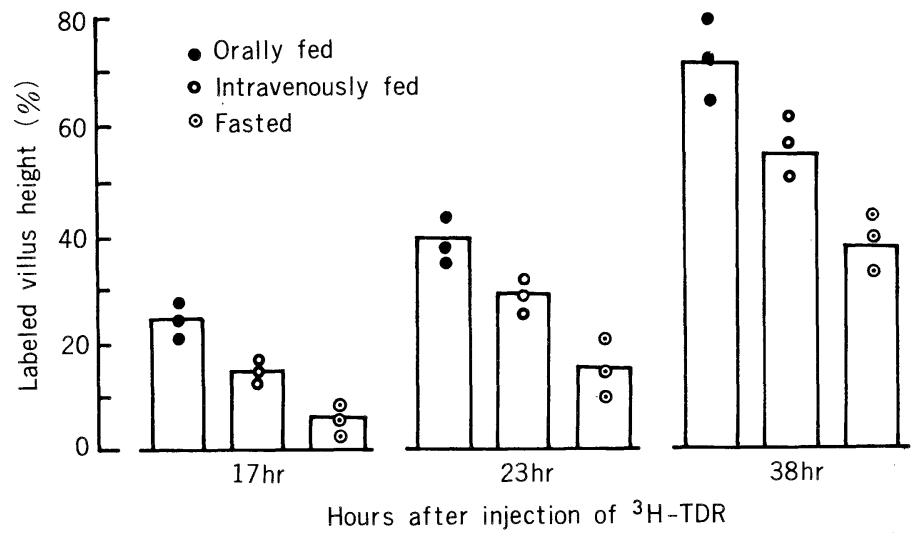

Fig. 2. The migration of the labeled cells along the length of the villus.

Table 2. Kinetics of cellular renewal in the jejunum of rats fed intravenously, orally or fasted.

\begin{tabular}{|c|c|c|c|c|c|}
\hline \multirow{3}{*}{ Group } & \multicolumn{5}{|c|}{ Parameter } \\
\hline & \multirow{2}{*}{$\begin{array}{c}\text { Villus } \\
\text { height } \\
\text { (cell no.) }\end{array}$} & \multicolumn{2}{|c|}{ Transit time } & \multirow{2}{*}{$\begin{array}{l}\text { Life span } \\
\text { (hr) }\end{array}$} & \multirow{2}{*}{$\begin{array}{l}\text { Migrating } \\
\text { speed } \\
\text { (cell no./hr) }\end{array}$} \\
\hline & & Crypt & Villus & & \\
\hline Intravenously fed & $91.2 \pm 1.5$ & 13.2 & 50.4 & 63.6 & 1.43 \\
\hline Orally fed & $99.8 \pm 2.0$ & 10.3 & 45.8 & 56.1 & 1.78 \\
\hline Fasted & $86.5 \pm 1.8$ & 18.2 & 78.2 & 96.4 & 0.90 \\
\hline Statistical & $\mathrm{O}>\mathrm{I} . \mathrm{V}$ & & & & \\
\hline comparison* & I.V. $>$ F & & & & \\
\hline
\end{tabular}

The value of villus height is the mean \pm SE of $20-30$ villi. * Indicates statistically significant difference among 3 groups, $p<0.05$.

peak was highest. In contrast to elution patterns of rats fed orally, elution patterns of fasted rats showed that there were high peaks of low molecular weight protein. On the other hand, elution patterns of rats fed intravenously showed high molecular weight proteins as a major peak near the void volume, similar to the case with rats fed orally although the elution patterns were less complex.

\section{Cell migration}

The crypt-villus columns were studied at each point and the presence or absence of labeling and mitosis were recorded for each cell position. The percentages of labeled cells on the villi of the epithelium in the intravenously, orally fed and fasted animals are illustrated in Fig. 2. The total cell number in the villus in the Vol. 27, No. 4, 1981 
Table 3. Plasma concentration of albumin, glucose and lipoprotein.

\begin{tabular}{|c|c|c|c|c|}
\hline & Intravenously fed & Orally fed & Fasted & $\begin{array}{c}\text { Statistical } \\
\text { comparison* }\end{array}$ \\
\hline Albumin ${ }^{\mathrm{a}}$ & $2.2 \pm 0.2$ & $2.3 \pm 0.3$ & $1.8 \pm 0.2$ & I.V. $>\mathrm{F} ; \mathrm{O}>\mathrm{F}$ \\
\hline Glucose $^{b}$ & $164 \pm 13$ & $182 \pm 6$ & $115 \pm 9$ & I.V. $>\mathrm{F} ; \mathrm{O}>\mathrm{F}$ \\
\hline \multicolumn{5}{|l|}{ Lipoprotein } \\
\hline $\mathrm{TC}^{\mathrm{c}}$ & $68.3 \pm 4.4$ & $88.5 \pm 2.8$ & $61.0 \pm 2.8$ & $\mathrm{O}>\mathrm{I} . \mathrm{V} . ; \mathrm{O}>\mathrm{F}$ \\
\hline HDL-C ${ }^{d}$ & $28.3 \pm 2.0$ & $42.1 \pm 2.6$ & $27.3 \pm 1.4$ & $\mathrm{O}>\mathrm{I} . \mathrm{V} ; \mathrm{O}>\mathrm{F}$ \\
\hline LDL-C $^{\mathrm{e}}$ & $26.4 \pm 2.9$ & $34.1 \pm 5.6$ & $33.5 \pm 2.4$ & N.S. \\
\hline $\mathrm{HDL} / \mathrm{TC}$ & $0.417 \pm 0.030$ & $0.474 \pm 0.026$ & $0.443 \pm 0.012$ & N.S. \\
\hline $\mathrm{HDL} / \mathrm{LDL}$ & $1.00 \pm 0.08$ & $1.27 \pm 0.13$ & $0.92 \pm 0.10$ & $\mathrm{O}>$ I.V.; $\mathrm{O}>\mathrm{F}$ \\
\hline
\end{tabular}

* Indicates statistically significant difference among 3 groups, $p<0.05$. N.S.: no significant difference between data sets, $p<0.05$. I.V., O and F: mean intravenously, orally and fasted, respectively. ${ }^{\text {a,b,c,d,e }}$ Values are expressed as $\mathrm{mg} / 100 \mathrm{ml}{ }^{\mathbf{c}}{ }^{\mathbf{c}}$ Total cholesterol, ${ }^{\mathrm{d}}$ high density cholesterol, ${ }^{\mathrm{e}}$ low density cholesterol.

intravenously fed animals decreased significantly in comparison with that in the orally fed animals. As shown in Table 2, it appeared that the prolongation of the cell life span in intravenously infused rats was comparable with that of orally fed rats.

\section{Plasma glucose and albumin}

The results are shown in Table 3. The plasma albumin and glucose concentration showed no difference between the rats fed intravenously and the rats fed orally. The values for the fasted rats were significantly lower than those for rats fed intravenously or orally.

\section{Plasma cholesterol and lipoprotein}

As shown in Table 3, plasma total cholesterol values of intravenously alimented rats were significantly lower than with orally alimented rats. There was no detectable difference in values between the rats fed intravenously and fasted rats.

HDL-cholesterol levels of the rats fed intravenously were significantly lower than those of rats fed orally. There was no significant difference between the rats fed intravenously and fasted rats. In contrast, LDL-cholesterol levels in intravenously or orally fed rats did not differ, nor did the HDL-cholesterol/Total-cholesterol ratio among all 3 groups. With regard to the HDL-cholesterol/LDL-cholesterol ratio, however, a marked difference between the rats fed orally and intravenously was found as well as between rats fed orally and fasting.

\section{DISCUSSION}

Tao et al.(2) determined the intravenous energy and nitrogen requirement of growing rats from weight gain and nitrogen balances. On the basis of that data, the 
composition of the intravenous infusates used in this experiment was designed. Actually, the final body weight of the rats was higher than their initial body weight. It therefore seems reasonable to assume that nitrogen balances were adequate.

The small intestinal mucosa can be influenced by a wide variety of factors. Two of these factors, oral intake-behavior and the volume of nutrient component, are recognized to be essential for maintenance of normal function of the small intestine. In this experiment, animals were not given the food in the intestinal tract although they were supplied with adequate levels of energy or protein. Reports have been made on the protein composition of the microvillus membrane obtained from human jejunum (6), suckling rat jejunum (7) and from developing rat (8). However, there are few studies on the composition of mucosal protein of rats fed intravenously, that is to say, luminal contents lacking food components. In this study, the typical elution patterns of mucosal protein of the rats fed intravenously or orally and those of fasted rats are reported. It seems that the rats fed intravenously showed a composition of mucosal protein different from that of rats fed orally or fasted, except for the similarity in rats fed intravenously or orally of a common high molecular weight protein peak.

The number of crypt and villus cells may be influenced by partial resection of the small intestine (9). A decrease in cell number was observed after experimental by-pass(10). Among the factors influencing small intestinal morphology and function, luminal factors seem to be very important. Cell migration in the rats fed intravenously appeared to be delayed when compared to the rats fed orally. In the fasted rats, cell migration appeared to be most delayed. These findings indicate that labeled cells in the rats fed intravenously synthesized less DNA, and that the rate of cell migration was also decreased.

DenBesten et al.(11) reported that serum insulin levels in animals fed intravenously were significantly higher than in animals fed orally, but that blood glucose levels did not differ from each other. In this experiment, blood glucose levels also support their results.

The use of fat-free feeding produced a sharp decline in plasma cholesterol levels. Even that cholesterol derived from the bile and intestinal mucosa would have lessened absorbability because of the absence of dietary fat (12). The further lowering of the plasma cholesterol level with intravenous feeding probably occurred because the more metabolically quiescent intestinal mucosa was no longer contributing the customary amount of synthesized cholesterol to the plasma. When gut was completely bypassed by means of an intravenous route of nutritional administration in man, the plasma cholesterol level was lower than with oral feeding (11).

There are few data available on the regulation of plasma-HDL cholesterol, except that it is generally inversely related to plasma triglycerides. Starzl et al. (13) have suggested that, in hiperlipoproteinemia, the route of nutrient or intestinal flow to the liver via the portal vein may be a significant factor in the regulation of the cholesterol metabolism in the steady state. Heretofore, the small intestine as well as liver have been presumed to be the primary source of lipoprotein and cholesterol 
(14). The hypothesis of DenBesten et al. (11) that intestine may itself be responsible for increased triglyceride synthesis induced by carbohydrate, confirms to the increasing recognition of the role of the intestinal mucosa in lipid synthesis. In this study, plasma cholesterol and HDL-cholesterol decreased greatly with animals having no luminal content although given a fat-free nutrient solution intravenously, thus suggesting that the intestinal mucosa may play a prime role in the synthesis of lipoprotein resulting from a fat-free diet.

\section{REFERENCES}

1) Kawamura, M., and Kimura, S. (1980): Effect of fasting versus parenteral alimentation on the rat small intestine. J. Nutr. Sci. Vitaminol., 26, 515-519.

2) Tao, R. C., Yoshimura, N. N., Chinn, I. B., and Wolfe, A. M. (1979): Determination of intravenous non-protein energy and nitrogen requirement in growing rats. J. Nutr., 109, 904-915.

3) Steiger, E., Vars, H. M., and Dudrick, S. J. (1972): A technique for long-term intravenous feeding in unrestrained rats. Arch Surg., 104, 330-332.

4) Matsuzawa, T. (1969): Radioautograph, ed. by Matsuzawa, T., Asakura Shoten, Tokyo, pp. 125-155.

5) Martinek, R. G. (1964): Evaluation of due-binding method for determination of serum albumin. Clin. Chem., 11, 441-447.

6) Maestracci, C., Schmitz, J., Preiser, H., and Crane, R. K. (1973): Proteins and glycoproteins of the human intestinal brush border membrane. Biochim. Biophys. Acta, 323, 113-124.

7) Galand, G., and Forster, G. G. (1974): Isolation of microvillus membrane from suckling-rats intestine. Biochem. J., 144, 293-302.

8) Seetharam, B., Yen, K. Y., Moog, F., and Alpers, D. H. (1977): Development of intestinal brush border membrane proteins in the rat. Biochim. Biophys. Acta, 470, 424-436.

9) Dowling, R. H., and Gleeson, M. H. (1973): Cell turnover following small bowel resection and by-pass. Digestion, 8, 176-190.

10) Gleeson, M. H., Cullen, J., and Dowling, R. H. (1972): Intestinal structure and function after small bowel by-pass in the rat. Clin. Sci., 43, 731-742.

11) DenBesten, L., Reyna, R. H., Connor, W. E., and Stegink, L. D. (1973): The different effects on the serum lipids and fecal steroids of high carbohydrate diets given orally or intravenously. J. Clin. Invest., 52, 1384-1393.

12) Esko, K., Lin, T. M., and Lvy, A. C. (1957): Capacity of human intestine to absorb exogenous cholesterol. J. Appl. Physiol., 11, 143-147.

13) Starzl, R. E., Chase, H. P., Putnam, C. W., and Porter, K. M. (1973): Portacavel shunt in hyperlipoproteinemia. Lancet, II, 940-944.

14) Ockner, R. K., Hughes, F. B., and Isselbacher, K. J. (1969): Very low density lipoproteins in intestinal lymph: origin, composition, and role in lipid transport in the fasting state. J. Clin. Invest., 48, 2029-2088. 